\title{
Stomach Contents of Snow Crab (Chionoecetes opilio, Decapoda, Brachyura) from the Northeast Newfoundland Shelf
}

\author{
Hubert J. Squires \\ 14 Solomons Drung, Portugal Cove-St. Philips \\ Newfoundland, Canada A1M 2C5 \\ and \\ Earl G. Dawe \\ Science Oceans and Environment Branch, Department of Fisheries and Oceans \\ P. O. Box 5667, St. John's, Newfoundland, Canada A1C 5X1
}

\begin{abstract}
A sample of about 1000 snow crabs (Chionoecetes opilio) from NAFO (Northwest Atlantic Fisheries Organization) Division 3K (Northeast Newfoundland Shelf), taken by bottom trawl for studies of their stomach contents, indicated that about 12 benthic or demersal prey types occurred in their diet from that area. The most frequently occurring prey types were sabellid polychaetes, crustaceans (shrimp, crabs and smaller crustaceans) and infaunal clams (Macoma calcarea). Shrimps (especially pink shrimp, Pandalus borealis) and fishes (especially capelin, Mallotus villosus) were the most important prey types with respect to their percentage contribution to the total food mass. Brittle stars (Ophiuroidea) were regularly preyed upon by males but were virtually absent from the stomach contents of mature females. Males preyed more heavily upon fish and infaunal prey types (polychaetes and clams) whereas females preyed more heavily on shrimp and readily-accessible epibenthic prey types (gastropods, crabs and sea urchins). Males appeared to be more capable predators than were mature females. Predation on fish was related to predator size for both sexes but was most commonly practiced by males that were larger than the maximum size of mature females. However predation on fish was also more commonly practiced by males than by mature females at comparable sizes. There were no other effects of predator size in the predation by males whereas predation by mature females on clams, shrimp, gastropods, sea urchins, and possibly polychaetes increased with predator size. Cannibalism was most frequently practiced by intermediate-sized crabs and more frequently by females than males. Cannibalism was more common in our study than in others reported to date and may represent an important densitydependent source of mortality that could affect recruitment levels and patterns.
\end{abstract}

Keywords: cannibalism, Chionoecetes opilio, mature females, Newfoundland, snow crab, stomach contents

\section{Introduction}

Snow Crab (Chionoecetes opilio (O. Fabricius, 1788)) is an important commercial species in the Northwest Atlantic, especially in the Newfoundland and Labrador area (Dawe and Colbourne 2002), where annual landings increased annually from about 10000 $\mathrm{t}$ during the late 1980's to about $69000 \mathrm{t}$ in 1999 (Dawe et al., 2002). Long-term trends in fishery performance have exhibited considerable temporal and spatial variation (Dawe et al., 2002), possibly reflecting variation in recruitment. There is some indication that trends in landings or commercial catch rates in some areas may display a regular periodicity, but time series are currently too limited to be conclusive.

It has been shown that early benthic stage snow crabs are cannibalized by larger conspecifics in the northern Gulf of Saint Lawrence (Lovrich and SainteMarie 1997) and it has been hypothesized that this size-dependent cannibalism may serve as an intrinsic density-dependent mechanism for adjustment of recruitment periodicity (Sainte-Marie et al., 1996). 
There is no information available on the diet composition of snow crab from the expansive eastern continental shelf fishery area between southern Labrador and the tail of the Grand Bank (NAFO Div. $2 \mathrm{~J}+3 \mathrm{KLNO}$ ). Some information is available from spatially limited studies in inshore areas on the east Coast (Miller and O'Keefe, 1981) and west Coast (Wieczorek and Hooper 1995), of insular Newfoundland, and Squires (1990 and 1996) provided a brief note on stomach contents of medium-sized snow crabs and other crabs from the Newfoundland, Labrador and Canadian arctic areas. However most of the available information on snow crab diet in Canadian Atlantic areas was derived from the southern and northern Gulf of St. Lawrence (Powles 1968; Brêthes et al., 1982 and 1984; Lefebre and Brêthes 1991; Lovrich and Sainte-Marie 1997). None of these studies have included mature females.

Our study was undertaken to describe the diet of snow crab, including mature females, on the northeast Newfoundland Shelf and to determine the possible existence and prevalence of cannibalism in this area.

\section{Materials and Methods}

\section{Sampling}

Snow crabs (986 specimens) were collected during 22 October-30 November 2000, on the northeast Newfoundland Shelf (NAFO Div. 3K, Fig. 1). Samples were collected during the annual fall multispecies bottom trawl survey of the Northwest Atlantic Fisheries Center (Dawe et al., 2002). That survey utilized a Campelen 1800 shrimp trawl in standard survey sets of $15 \mathrm{~min}$ duration (McCallum and Walsh, 2002). Spatial allocation of survey sets is based upon a stratified random sampling scheme (Doubleday, 1985).

Sampling of male snow crabs from the trawl catch of each set, for stomach analysis, was stratified by size. At each set, a maximum of three males was randomly selected for each of 5 carapace width $(\mathrm{CW})$ groups as follows: less than $40 \mathrm{~mm} \mathrm{CW}, 40-59 \mathrm{~mm}$ $\mathrm{CW}, 60-75 \mathrm{~mm} \mathrm{CW}, 76-94 \mathrm{~mm} \mathrm{CW}$ and larger than $94 \mathrm{~mm} \mathrm{CW}$. In addition, as many as 3 mature females were randomly selected from each survey catch. All specimens (851 males and 135 females) were quickfrozen as soon as possible after collection.

In the laboratory, after the crabs were thawed, the stomach was dissected from each crab with shears by cutting open the gastric area of the carapace (Fig. 2), clearing attached musculature and digestive or gonad organs from the stomach, cutting off the esophagus and lifting out the stomach. The intact stomach was weighed on a precision electronic balance to the nearest $0.01 \mathrm{~g}$. The stomach was slit open ventrally to avoid the gastric mill, and cut around the edge to open it up and expose its contents. The contents were first examined under low power of a dissecting microscope, and recognizable items were weighed to the nearest $0.01 \mathrm{~g}$. Several small samples of the contents were then taken and spread in water on a glass slide, covered with a cover slip and examined under high power of a light microscope. Even apparently empty stomachs were sampled and scrapings from the stomach put on a glass slide for examination. The stomach was then washed in water in a petri dish to remove residual material to be further examined under the dissecting microscope. The stomach was dried off with a tissue to remove excess water and re-weighed. The weight of the empty stomach was subtracted from its original total weight to estimate the weight of the total stomach contents.

\section{Identification of Stomach Contents}

Criteria used for identification of items found in stomach contents of snow crabs were as follows:

Fish. Slender bones of ribs and vertebrae or pieces of bone (denser than setae or spines of crustaceans), scales or scutes, otoliths, whitish muscular tissues, and fatty residue, especially of capelin (Mallotus villosus). Bony scutes in spiny lumpfish (Eumicrotremus spinosus) were definitive.

Foraminifera. Small, circular structures, with concentric whorls of crystalline material, (pinkish from this area).

Sponge. Non-tapered fine spicules, translucent, reflecting, monaxon (of siliceous sponges in this area).

Hydroid. Dark brown, branching, plant-like structures.

Gastropod. Fragments of thin opalescent shell, part of helical coil of marine snail.

Clam shell. Fragments of dull whitish bivalve shell. Rarely, a small intact shell; primarily Macoma calcarea.

Polychaete. Brownish or yellowish stout tapering irridescent chaetae, stout dark brown jaws, various other specifically shaped chaetae, and pieces of sand tubes (sand particles glued together); mostly sabellid worms. 


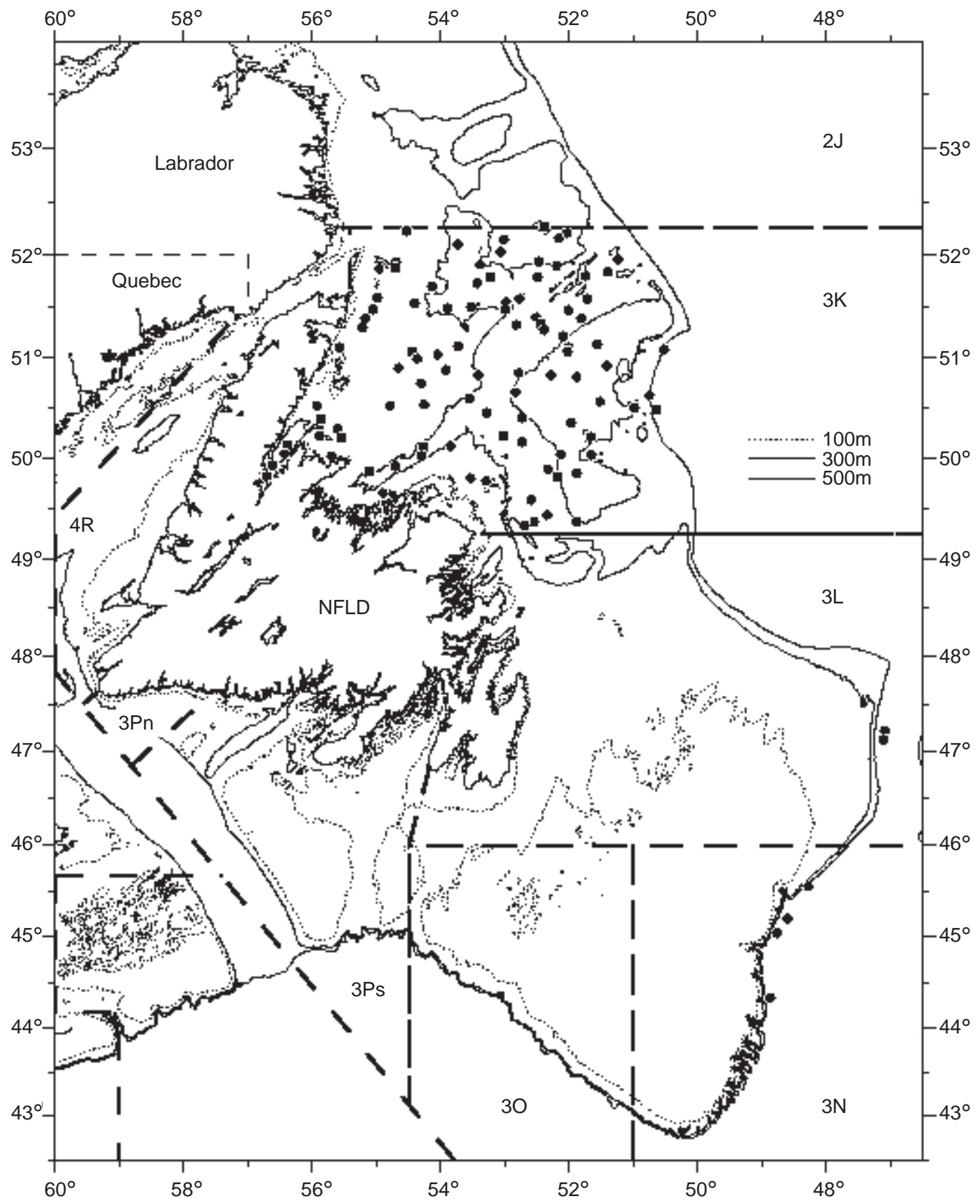

Fig. 1. Map of the area of collection of snow crabs for stomach content analyses. NAFO Div. 3K: Northeast Newfoundland Shelf.

Crustaceans. This represents crustaceans other than shrimps or crabs; fragments of chitinous shells, mostly of amphipods, but also copepods and other crustaceans.

Shrimps. Recognizable fragments of shrimps: pieces of antennae, uropods, rostrum, pieces of abdominal musculature, carapace, mandibles, mouth parts, fine plumose setae.
Crabs. Carapace fragments with nodular surface, small translucent hooked setae, mandibles, mouthparts, partly digested pieces of chitin with knobs showing microscopically as small concentric circles or spots.

Sea Urchin. Pieces of opaque calcareous shell with knobby surface, spines with crystals at center of translucent column and densely crystalline base. 
Brittle Star. Densely crystalline polygonal pieces plus stud-like pieces of opaque white crystalline material.

Diatoms. Centric: circular with radial iridescence. Pennate: oblong, netted or various translucent surface.

Detritus. Digested or dark flocculent amorphous material.

\section{Results}

\section{Composition of Stomach Contents}

Only about $5 \%$ of stomachs from males and $8 \%$ of those from mature females were found to be completely empty (Table 1). However many stomachs contained only trace amounts of food $(<0.01 \mathrm{~g})$ that could not be identified to prey type by microscopic examination but did not contribute to the prey composition by weight. Stomach contents usually reflected a well-mixed diet, with about 3-7 prey types commonly occurring in any stomach.

The most frequently occurring items in stomachs were infaunal prey types; polychaetes and clams (Fig. $3 a)$. Polychaete remains (mostly sabellid worms) were represented in $90 \%$ and $81 \%$ of stomachs of males and females respectively. Clams (primarily Macoma spp.) occurred in $48 \%$ and $43 \%$ of male and female stomachs respectively.

The most important prey types with respect to their percentage contribution to the total food mass were shrimp and fish (Fig. 3b). The percentage contributed by shrimp prey was much higher for females $(65 \%)$ than for males $(22 \%)$, whereas the reverse was true for fish prey, which contributed 35\% and $5 \%$ of the total weight of stomach contents for males and females respectively. The most frequently identified shrimp species was northern or pink shrimp (Pandalus borealis) but other shrimps included other Pandalids (eg. Pandalus montagui and Dichelopandalus leptocerus) as well as unspecified Penaeids, Aresteids, and Oplophorids. The predominant fish prey species was capelin (Mallotus villosus), but other fishes identified included Atlantic spiny lumpsucker (Eumicrotremus spinosus) and redfishes (Sebastes spp.).

Observations of capelin remains in stomachs indicated that at least some of the capelin likely resulted from predation on live fish rather than scavenging of dead post-spawners. The texture (with skin still attached) and fresh smell of some capelin chunks suggested fresh prey. Also otoliths and pieces of otoliths, as well as absence of gonad remains indicated that capelin prey were generally younger

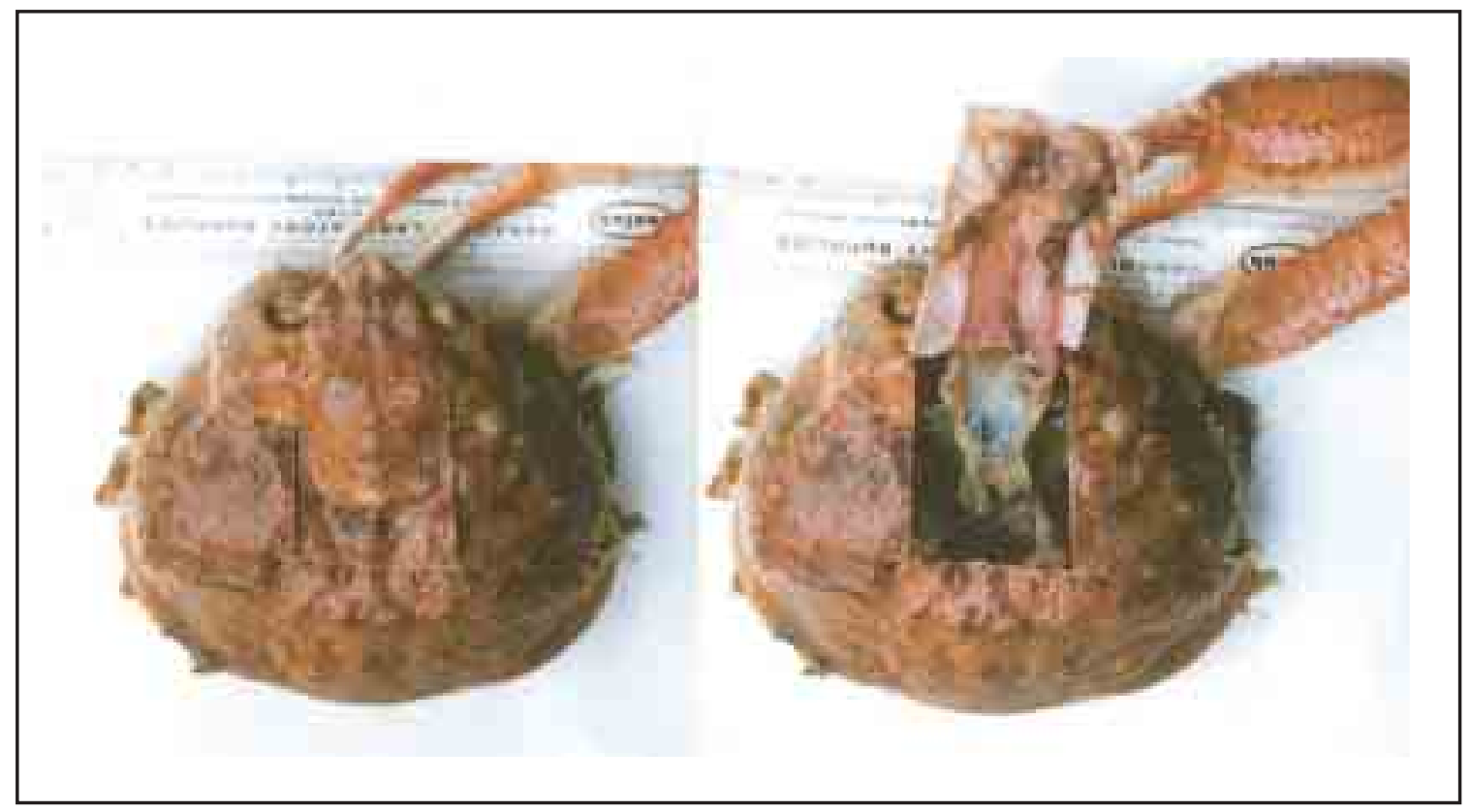

Fig. 2. Photograph of snow crab (Chionoecetes opilio) with cuts of the gastric area of the carapace to show stomach ready to be lifted out. 
TABLE 1. Numbers of sets, size range, stomachs examined, and numbers of empty stomachs of male and female snow crabs from the Northeast Newfoundland shelf.

\begin{tabular}{lccccc}
\hline \hline Sex & $\begin{array}{c}\text { No. } \\
\text { of Sets }\end{array}$ & $\begin{array}{c}\text { Size range } \\
\text { CW }- \text { mm }\end{array}$ & $\begin{array}{c}\text { No. of } \\
\text { Exomachs } \\
\text { Examined }\end{array}$ & $\begin{array}{c}\text { No. of } \\
\text { Stomachs } \\
\text { Empty }\end{array}$ & $\begin{array}{c}\text { Percent of } \\
\text { Stomachs } \\
\text { Empty }\end{array}$ \\
\hline Males & 114 & $14-136$ & 847 & 46 & 5.4 \\
Females & 51 & $36-72$ & 139 & 11 & 7.9 \\
\hline
\end{tabular}
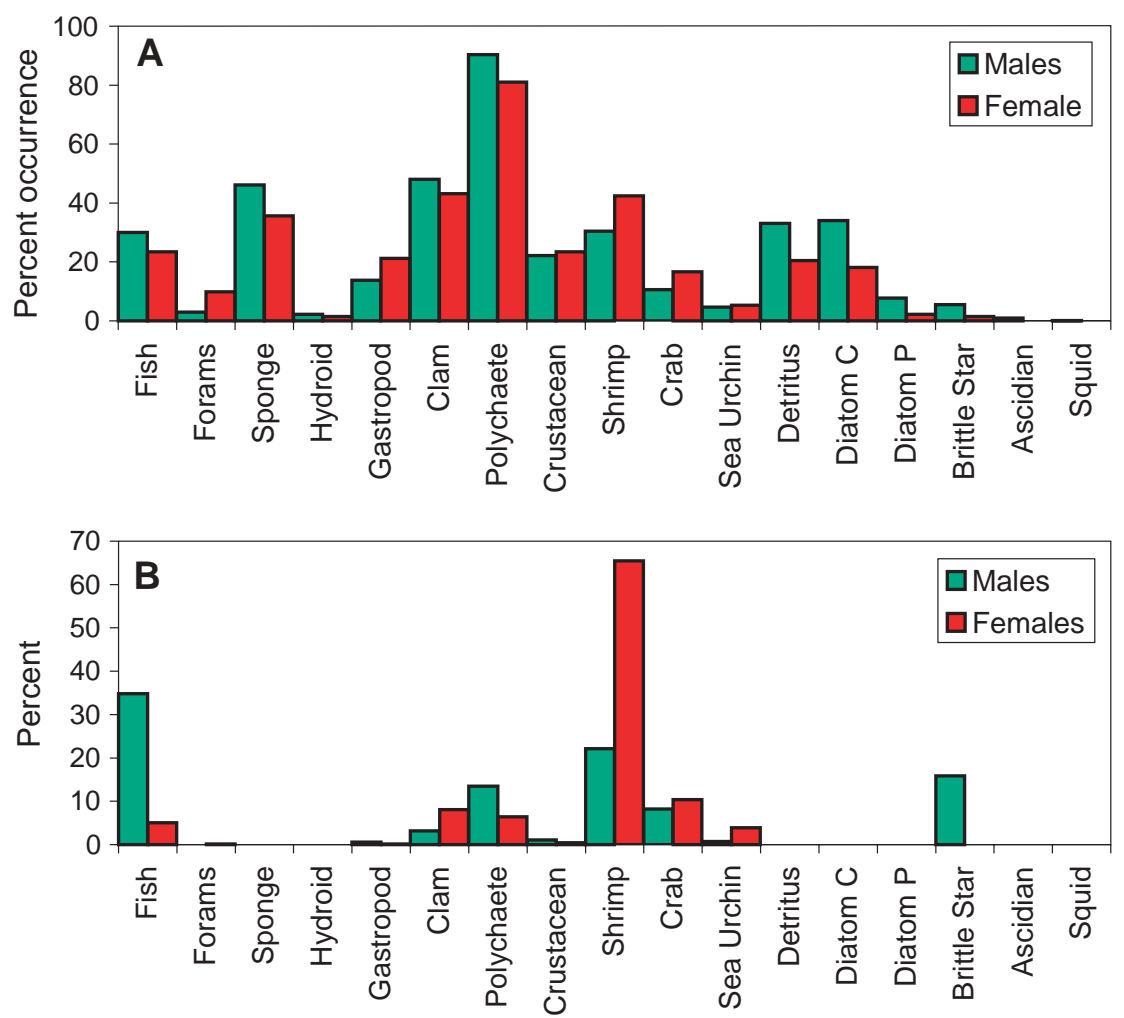

Fig. 3. Percent occurrence (A) and percentage composition by weight (B) of prey items in stomach contents of snow crab, by sex, from the Northeast Newfoundland Shelf (NAFO Div. 3K ) during October-November, 2000.

and smaller than mature capelin. Rarely, a whole small capelin was found in a stomach with its orientation reflecting that it had been injested head-first, as would be expected in subduing and consuming live prey.

Predation on crabs was relatively prominent, as reflected by both frequency of occurrence $(10.6 \%$ for males and $16.7 \%$ for females, Fig. 3a) and percent contribution by weight $(8.2 \%$ for males and $10.4 \%$ for females, Fig. 3b). This predation, primarily reflecting cannibalism of smaller snow crabs, was more common by mature females than by males.

Echinoderms were represented by brittle stars (Ophiuroidea) and sea urchins (Echinoida). Neither of these occurred in more than $6 \%$ of stomachs of either sex (Fig. 3a). However, brittle stars represented $15.9 \%$ of the total weight of male stomach contents while contributing virtually nothing to the food mass of mature females (Fig. 3b). 
Several prey types occurred commonly in stomachs but contributed very little to the total food mass (Fig. 3), including gastropods, sponges, diatoms, and crustaceans other than shrimps and crabs (primarily amphipods, but also copepods and other small crustaceans). Other prey types were quite uncommon, including foraminiferans, hydrozoans, tunicates (Ascidiacea), and squid (Gonatus sp.). Innanimate objects were rarely encountered, including pieces of rope, string and plastic garbage bag, each found in only a single stomach.

\section{Effects of predator size and sex}

The weight of stomach contents was directly related to predator size for both sexes (Fig. 4). A linear model adequately described this relationship for females, but when applied to the much broader size range of males there was some bias, suggesting that a non-linear model (e.g. exponential) may best describe the relationship across the full size range. There was no difference between the sexes in stomach contents weight-at-CW within the limited size range common to both sexes. There was great variation at largest carapace widths of males, largely due to small sample sizes. Number of stomachs examined ranged only $0-3$ for carapace widths larger than $125 \mathrm{~mm}$.

We grouped the data by $3 \mathrm{~mm} \mathrm{CW}$ intervals to examine effects of size on predation on the principal prey types. While this reduced variability associated with small sample sizes, the number of stomachs examined remained small for the extreme size groups of females and the largest size groups of males (Fig. 5). Sample sizes by $3-\mathrm{mm} \mathrm{CW}$ group were most comparable between the sexes from 42 to $54 \mathrm{~mm} \mathrm{CW}$, where number of stomachs examined by sex ranged 12-23.

The percent occurrence of fish was directly related to size for both sexes (Fig. 6). However there was no clear effect of size on percent occurrence of any other prey types in stomachs of males. In contrast the percent occurrence of most prey types increased with size of mature females. Besides fish, these prey types included polychaetes, clams, shrimp, gastropods, and sea urchins (Fig. 6). Only for crabs and crustaceans (other than shrimp or crabs) was percent occurrence in female stomachs apparently unrelated to size. The
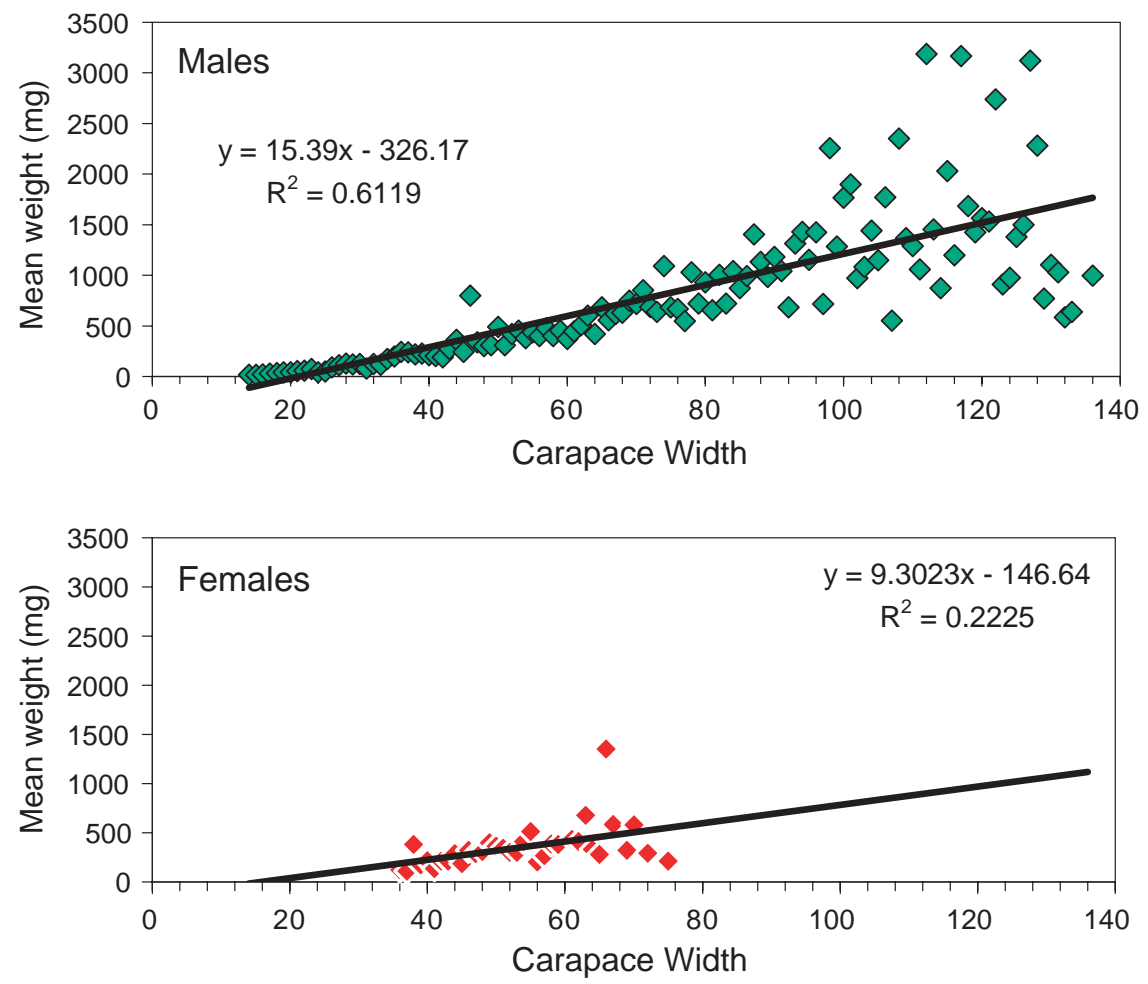

Fig. 4. Mean weights (mg) of snow crab stomach contents, by sex and 3-mm carapace width group, from the Northeast Newfoundland Shelf (NAFO Div. 3K ) during October-November, 2000 with linear regression models overlain. 


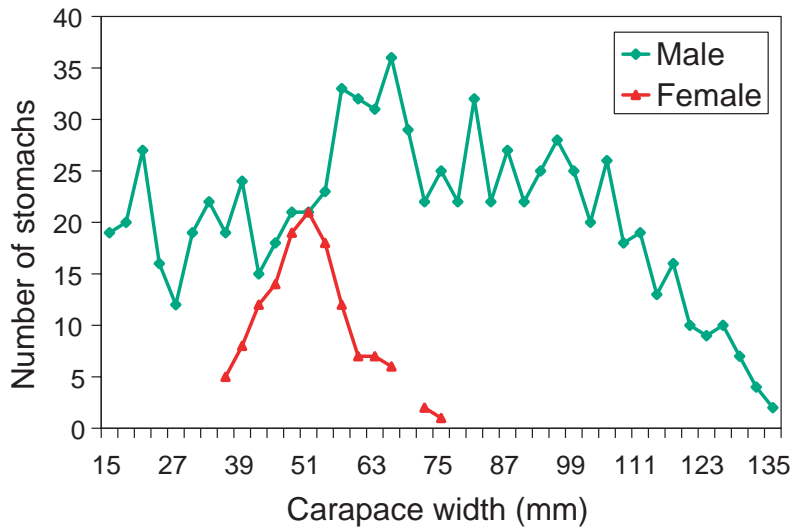

Fig. 5. Number of snow crab stomachs examined by sex and 3$\mathrm{mm}$ carapace width group, from the Northeast Newfoundland Shelf(NAFO Div. 3K) during OctoberNovember, 2000.

great difference between the sexes in occurrence of brittle stars was not related to size differences between the sexes. Brittle stars occurred in $20-59 \%$ of stomachs of males for all but one of the size groups common to both sexes, whereas they occurred in only one of those size groups (65-67 mm CW), at 16\% occurrence, for females.

We directly compared size relationships between the sexes for each of the most important prey types (Fig. 7 and 8). While there was no apparent size relationship in the percent occurrence of polychaetes in stomachs of males there appeared to be a slight direct relationship across the more limited size range of females (Fig. 7a). The percent occurrence of clams was not related to size for males but increased with size for females (Fig. 8b). Clam occurrence was greater for males than females at $36-57 \mathrm{~mm} \mathrm{CW}$ but became greater for females than males at $61-75 \mathrm{~mm} \mathrm{CW}$.

Percent occurrence of fish increased across the broad male size range from peaks of about $20 \%$ occurrence at $15-27 \mathrm{~mm} \mathrm{CW}$ to peaks of about $50 \%$ occurrence at $69-96 \mathrm{~mm} \mathrm{CW}$, mostly larger than the maximum size of mature females. It declined in larger males to $10 \%$ at about $121 \mathrm{~mm}$ (Fig. 6c). An increase in largest males (129-135 mm CW) may be an artifact related to low sample sizes (Fig. 5). While the percent occurrence of fish also increased with size for mature females, it was slightly higher in stomachs of comparably-sized males for those size groups that were best sampled for both sexes $(45-63 \mathrm{~mm} \mathrm{CW}$, Fig. $7 c)$.
The percent occurrence of both shrimp and gastropods (Fig. 7 d-e) was not related to size for males but increased with size for females, as was also true for clams (Fig.7b). Shrimp occurrence (Fig. 7d) was similar between the sexes at about 36-42 $\mathrm{mm} \mathrm{CW}$, but was greater for females than males in 7 of the 8 larger CW groups from $45-72 \mathrm{~mm} \mathrm{CW}$. Gastropod occurrence (Fig. 7e) showed no consistent difference between the sexes at about $36-48 \mathrm{~mm} \mathrm{CW}$, but was greater for females than males in 6 of the 7 larger $\mathrm{CW}$ groups from $51-72 \mathrm{~mm} \mathrm{CW}$.

The percent occurrence of other crustaceans showed no size relationships and no clear difference between sexes (Fig. 8a). It was highly variable, ranging $10-43 \%$ within the size range common to both sexes.

Percent occurrence of crabs as prey was highly variable across the broad male size range (Fig. 8b), and so size relationships were unclear. It ranged 0 $37 \%$ for males but appeared to be most consistently high (about $14-27 \%$ occurrence) at intermediate sizes of $66-81 \mathrm{~mm} \mathrm{CW}$. Crab remains were totally absent from 32 male stomachs encompassing the 5 largest size groups (123-135 $\mathrm{mm} \mathrm{CW})$. Crabs were more common in stomachs of females than in those of males for most of the 3-mm CW groups common to both sexes.

\section{Discussion}

\section{Diet Composition}

The stomach contents of snow crabs from the northeast Newfoundland Shelf reflected a broad spectrum of prey types that included polychaetes (mostly sabellid worms), fish (mostly capelin), shrimp (mostly pink shrimp), crab (mostly snow crab), other small crustaceans (mostly amphipods), mollusks (gastropods and Macoma sp. clams) and echinoderms (brittle stars and sea urchins). However, it is not possible to determine the relative importance of these prey types in the snow crab diet based on the stomach contents data. The importance of fish and crustaceans (shrimp, crabs and other crustaceans) in the diet was probably well represented by the stomach contents data because diagnostic hard structures (bones and exoskelleton) were likely consumed consistently. Also the most prominent prey items (capelin and shrimp) were relatively large with firm musculature that digests slowly. Hence these prey types were relatively well represented by both their percent occurrence and 

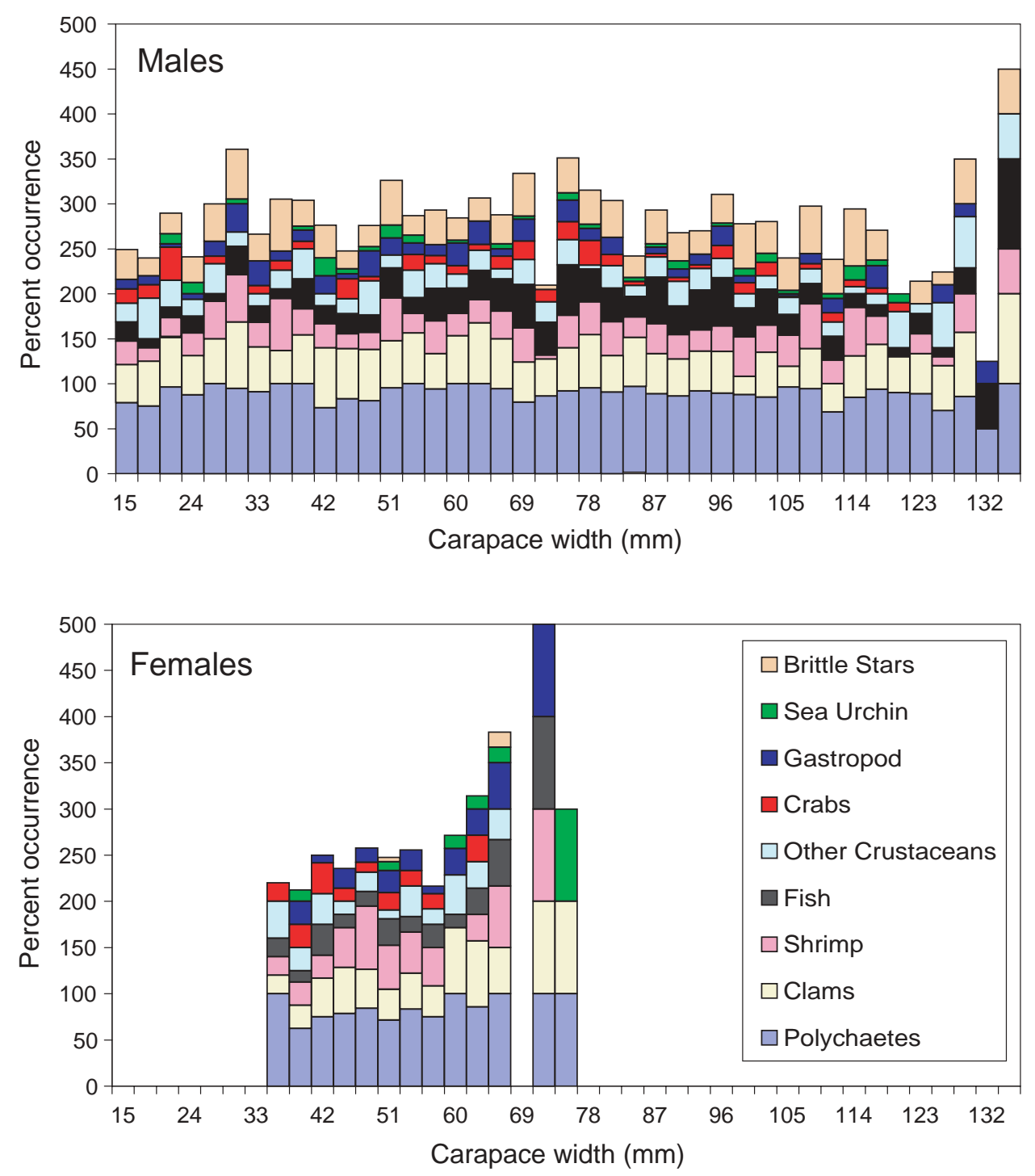

Fig. 6. Cumulative percent occurrence of the important prey types in stomach contents of snow crab, by sex and 3-mm carapace width group, from the Northeast Newfoundland Shelf (NAFO Area 3K) during October-November, 2000.

their percent contribution to the total food mass. In contrast, the importance of bivalve and gastropod mollusks in the diet may have been under-represented by the stomach contents data, because diagnostic shell may not have been consistently consumed in this predation and soft viscera would be unidentifiable and quickly digested. Despite these considerations clams ranked second in percent occurrence and sixth in percent contribution by weight, indicating that it was a very important component of the diet. The importance of polychaetes was likely over-represented by their percent occurrence because polychaete setae were commonly retained in folds of stomachs that were otherwise empty. However, that this soft-bodied and easily-digested prey type ranked third in percent contribution by weight indicates that it was an important component of the diet.

The importance of crabs (predominantly from cannibalism) and echinoderms (brittle stars and sea urchins) in the diet was probably well-represented in the stomach contents data. These prey types appeared to be of lesser importance than the four main prey types (polychaetes, clams, fish and shrimp). Prey types that featured prominently in percent occurrence but contributed very little by weight were relatively 

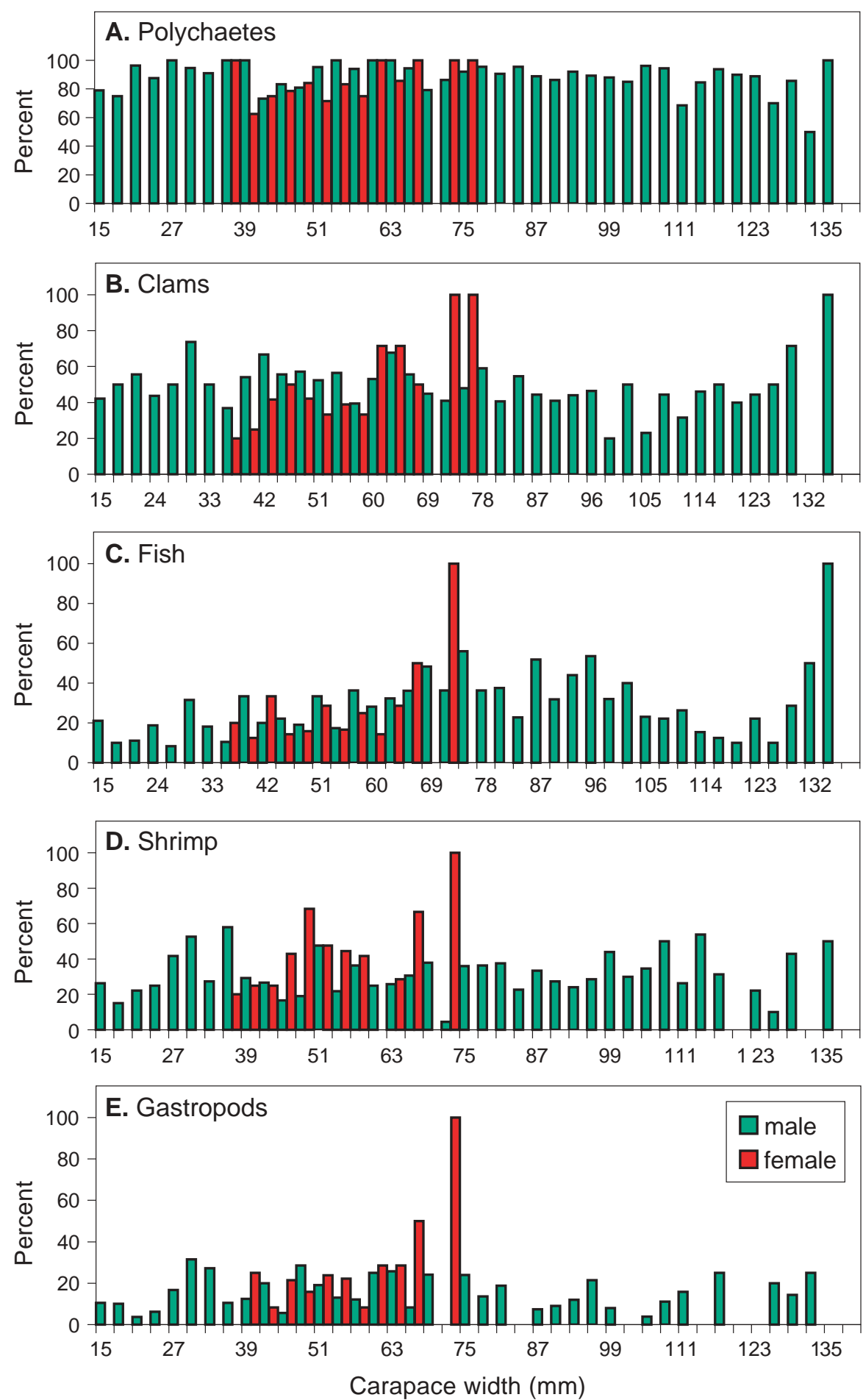

Fig. 7. Percent occurrence of (A) polychaetes, (B) clams, (C) fish, (D) shrimp and (E) gastropods in stomach contents of snow crab, by sex and 3-mm carapace width group, from the Northeast Newfoundland Shelf (NAFO Div. 3K) during October-November, 2000. 

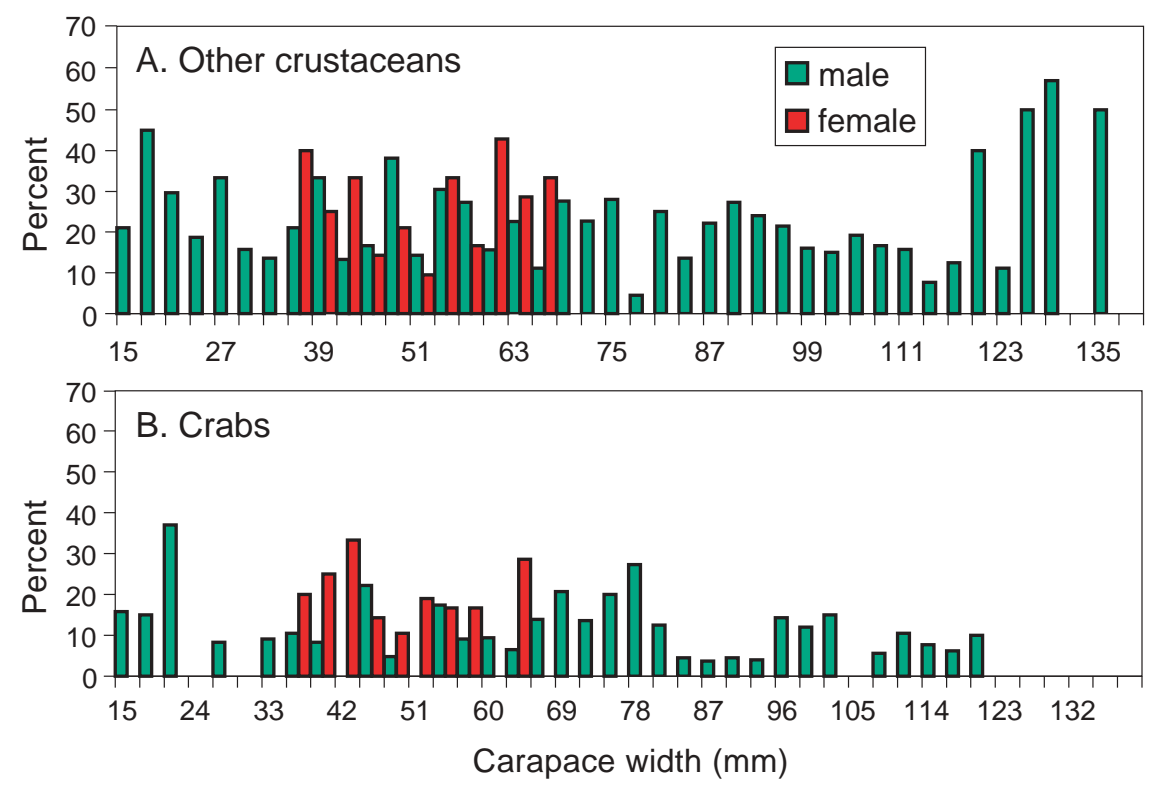

Fig. 8. Percent occurrence of (A) small crustaceans and (B) crabs in stomach contents of snow crab, by sex and 3-mm carapace width group, from the Northeast Newfoundland Shelf(NAFO Div. 3K) during October-November, 2000.

unimportant. These are either very small-bodied (eg. diatoms) or have distinctive diagnostic hard structures that were retained for long periods (eg. sponge spicules).

Other studies have reported prey composition only as frequency of occurrence (Miller and O'Keefe 1981, Wieczorek and Hooper 1995, Brêthes, et al., 1982, 1984, Lefebvre and Brêthes, 1991, Lovrich and Sainte-Marie 1997). The most frequent prey type in our study was polychaetes, with crustaceans (shrimp, crab and small crustaceans) and mollusks (clams and gastropods) being also frequent. Miller and O'Keefe (1981) also found, from a limited study of large males (>60 $\mathrm{mm} \mathrm{CW}$ ) in Conception Bay (east coast of Newfoundland), that polychaetes and clams were the most frequent prey types. However, unlike our results they found that Ophiuroids were much more frequent than crustaceans. Wieczorek and Hooper (1995), found, unlike any other studies, that fish was the most frequent prey type in large males $(>60 \mathrm{~mm} \mathrm{CW})$ from Bonne Bay (west coast of Newfoundland, eastern Gulf of St. Lawrence), which they attributed to scavenging of discarded bait. Aside from this high frequency of fish, their results were similar to ours with polychaetes, crustaceans, mollusks and echinoderms ranking in decreasing order of importance.
Lefebvre and Brêthes (1991) found, somewhat similar to our results, that crustaceans and polychaetes were the most frequent prey types in stomachs of small snow crabs $(<75 \mathrm{~mm} \mathrm{CW})$ from Baie des Chaleurs, Gulf of St. Lawrence during summer 1986-1987, with mollusks being less frequent. This differs from Powles (1968) who found that in the same general area mollusks (bivalves especially, but also gastropods) represented the most frequent prey category during summer 1967, with crustaceans (amphipods), polychaetes, and echinoderms (ophiuroids) also being frequent.

Although the relative importance of various prey types in the Gaspé Area (Powles 1968) differed from both the nearby Baie des Chaleurs (Lefebvre and Brêthes 1991) and the northeast Newfoundland shelf (our study), the relative effects of spatial and temporal differences versus methodological differences are unknown. Evaluating such effects is especially problematic when comparisons are based only on frequency of occurrence data because such data are strongly affected by level of detail in examining stomachs for small retained items. The relatively low frequency of empty stomachs in our study and high frequency of very small items (e.g. diatoms) and retained items (e.g. sponge spicules) suggests that 
examination of stomachs was more detailed in our study than in most of the others.

\section{Effects of predator size and sex}

Ours is the first study to describe the diet of mature females and compare it with that of males. Generally, males preyed more heavily on fish and infaunal items (ploychaetes and clams), whereas mature females preyed more heavily on shrimp and epibenthic prey types (gastropods, smaller crabs and sea urchins). A notable exception to this was the common predation, by males only and of all sizes, on brittle stars. We feel that these differences reflect greater ability of males than females to capture fish and infaunal prey types, due to their longer legs and greater mobility. Males, especially adults with enlarged chelae, may also be more capable of injesting prey types with external shells (clams) or tough integuments (brittle stars).

The greater importance of fish in the diet of males than in that of females was primarily due to size effects. Predation on fish was directly related to predator size for both sexes but was most frequently practiced by males that were larger than the maximum size of females. However occurrence of fish was also slightly higher for males than for females of comparable size. These direct size relationships support our assertion that fish remains in stomachs reflect primarily predation on live fish as opposed to scavenging only. Powles (1968) reported that fish consumed by snow crabs in the Gulf of St. Lawrence were about $10-15 \mathrm{~cm}$ in length, implying scavenging, whereas fish prey in our study were mostly capelin of smaller size, consistent with our suggestion that this reflects predation rather than scavenging of postspawning adult capelin. Lovrich and Sainte-Marie (1997) also found that frequency of fish increased with size of males from the northern Gulf of St. Lawrence and they concluded that this fish resulted from predation on live fish.

Predation on most other prey types (shrimp, clams, gastropods, sea urchins, and possibly polychaetes) was directly related to predator size for females but not apparently for males. Largest females preyed more heavily on shrimp than did comparablysized males, suggesting prey selection and predation on live shrimp. Smallest mature females preyed less heavily on clams than did comparably-sized males suggesting that at those sizes mature females may be less capable of either finding or ingesting infaunal clams than are males. Of the most important prey categories only the small crustaceans and crabs showed no increase in frequency with female size, suggesting that all sizes of mature females were capable of preying upon these readily available and poorly mobile prey types. The size relationships in predation by mature females that were not apparent in predation by males, suggest that small females in particular are less capable as predators than are comparably-sized males.

While there are no other studies that include mature females, Lovrich and Sainte-Marie (1997) have shown analogous size relationships in immature crabs and adolescent males that were unclear in adult males. They found a distinct shift in the diet of immature crabs plus adolescent males from predominantly small crustaceans (amphipods) in smallest crabs to predominantly infaunal polychaetes and bivalves at about $60 \mathrm{~mm} \mathrm{CW}$ and further increases in shrimp and fish occurrence to about $70 \mathrm{~mm} \mathrm{CW}$. This implies that the difference in size relationships between the sexes in our study may be due to inclusion of mature males and that immature males may show size relationships somewhat similar to our mature females.

Crabs (primarily smaller snow crabs) represented an important component of the diet, ranking third in percent contribution by weight. Cannibalism was more commonly practiced by females than males at any given size. This may reflect selection of this readily available and easily captured epibenthic prey type by females. Cannibalism, in our study, was reflected in $11 \%$ and $17 \%$ of stomachs of males and females respectively, higher than the overall $8 \%$ occurrence reported by Powles (1968) for the Gaspé area of the Gulf of St. Lawrence, and 7\% reported by Lovrich and Sainte-Marie (1997) for the northwest Gulf of St. Lawrence and estuary. The size range of our cannibalistic males was generally similar to that in the northwest Gulf and estuary, with males larger than about $120 \mathrm{~mm}$ not cannibalizing. Lovrich and SainteMarie (1997) found considerable annual and seasonal variation in prevalence of cannibalism. They also showed that cannibalism (on smaller snow crabs) was overall more prevalent at shallow than deep bottom water depths. We hypothesize that such a depth effect occurs in our study area because smallest males appear to be more prevalent at shallow than at greater depths (Dawe and Colbourne 2002). The high prevalence of cannibalism in our study relative to others is consistent with the hypothesis that cannibalism of early benthic stages by larger snow crabs may represent an intrinsic 
density-dependent mechanism for maintaining a regular recruitment periodicity (Sainte-Marie et al. (1996).

\section{Acknowledgements}

Appreciation is expressed for a Contract on Snow Crab stomachs from the Department of Fisheries and Oceans to one of us (HJS). We thank Dr. Craig Squires for reading an early draft of the manuscript, and Jeremy Squires for help with computer procedures in an earlier draft also.

\section{References}

BRÊTHES, J.-C. F., G. DESROSIERS and F. COULOMBE. 1982. Food of the snow crab (Chionoecetes opilio) from the southwestern part of the Gulf of St. Lawrence (Chaleur Bay area). Alaska Sea Grant Report 8210: 319-335.

1984. Aspects de l'alimentationet du comportement alimentaire du crabe-des-neiges, Chionoecetes opilio (O. Fabr.) dans le sudouest du Golfe du St.-Laurent (Decapoda, Brachyura). Crustaceana, 47: 235-244.

DAWE, E. G., and E. B. COLBOURNE. 2002. Distribution and demography of snow crab (Chionoecetes opilio) males on the Newfoundland and Labrador shelf. In: Crabs in Cold Water Regions: Biology, Management, and Economics. A. J. Paul, E. G. Dawe, R. Elner, G.S. Jamieson, G. H. Kruse, R. S. Otto, B. Sainte-Marie, T. C. Shirley, and D. Woodby (eds.). University of Alaska Sea Grant, AK-SG-02-01, p. 577-594.

DAWE, E. G., H. J. DREW, P. J. VEITCH, R. TURPIN, P. G. O'KEEFE, and P. C. BECK. 2002. An assessment of New-foundland and Labrador snow crab in 2001. CSAS Res. Doc., No. 2002/050, 51 p.

DOUBLEDAY, W. G. 1981. Manual on Groundfish surveys in the Northwest Atlantic. NAFO Sci. Coun. Studies, 2: 7-55.

LEFEBVRE, L. and J. -C. F. BRÊTHES. 1991. Influence de la croissance et du facteurs du milieu sur l'alimentation du crabe des neiges, Chionoecetes opilio (O. Fabricius), dans le sud-ouest du Golfe du Saint-Laurent. Can. J. Zool., 69: 489-494.

LOVRICH, G. A., and B. SAINTE-MARIE. 1997. Cannibalism in the snow crab, Chionoecetes opilio (O. Fabricus) (Brachyura: Majidae), and its potential importance to recruitment. J. Exp. Mar. Biol. Ecol., 211: $225-245$.

MCCALLUM, B. and S. J. WALSH. 2002. An update on the performance of the Campelen 1800 during the bottom trawl survey in NAFO subareas 2 and 3 in 2001, NAFO SCR Doc., No. 32, Serial No. N4643, 16 p.

MILLER, R. J. and P. G. O'KEEFE. 1981. Seasonal and depth distribution, size and molt cycle of the spider crabs, Chionoectes opilio, Hyas araneus and Hyas coarctatus in a Newfoundland Bay. Can. Tech. Rep. Fish. Aquat. Sci., 1003, iv $+18 \mathrm{p}$.

POWLES, H. 1968. Distribution and biology of the spider crab, Chionoectes opilio in the Magdalen Shallows, Gulf of St. Lawrence. Fish. Res. Board Can. Manuscr. Rept. Series, 997: 1-106.

SAINTE-MARIE, B., J-M. SÉVIGNY, B. D. SMITH, and G. A. LOVRICH. 1996. Recruitment variability in snow crab Chionoecetes opilio: pattern, possible causes, and implications for fishery management. In: Proceedings of the International Symposium on the Biology, Management, and Economics of Crabs from High Latitude Habitats. B. Baxter (ed). Lowell Wakefield Fish. Symp. Ser., Alaska Sea Grant Coll. Program Rep., No. 96-02, p. 451-478.

SQUIRES, H. J. 1990. Decapod Crustacea of the Atlantic coast of Can. Bull. Fish. Aquat. Sci., 221: 532 p.

1996. Decapod Crustaceans of Newfoundland, Labrador and the Canadian Eastern Arctic. Can. Manuscr. Rep. Fish. Aquat. Sci., 2359: 235 p.

WIECZOREK, S. K. and R. G. HOOPER. 1995. Relationship between diet and food availability in the snow crab, Chionoecetes opilio (O. Fabricius) in Bonne Bay, Newfoundland. J. Crustac. Biol., 15: 236-247. 